Trakya Üniversitesi

Eğitim Fakültesi Dergisi

XV. Uluslararası Katılımlı Sınıf Öğretmenliği

Eğitimi Sempozyumu (11-14 Mayıs 2016)

USOS 2016 Özel Sayısı, 162-177

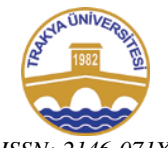

ISSN: 2146-071X
Trakya University

Journal of Education Faculty

XV. International Primary Teacher Education

Symposium (11-14 May 2016)

IPTES 2016 Special Issue, 162-177

Doi: $10.24315 /$ trkefd.366706

Geliș Tarihi: 28.11.2016

Yayına Kabul Tarihi: 27.07.2017

\title{
Okul Öncesi Öğretmenlerinin Bireyselleştirilmiş Eğitim Programı Hazırlanmasına İlişkin Görüşleri ${ }^{1}$
}

\section{Preschool Teachers' Opinions/Views on Developing the Individualized Education Program}

\author{
Deniz TEKIN ERSAN ${ }^{2}$, Seda ATA $^{3}$
}

\begin{abstract}
Öz: Ülkemizde özel gereksinimi olan çocuklar için erken müdahalenin gerçekleştiği kurumlardan biri okul öncesi genel eğitim kurumlarıdır. $\mathrm{Bu}$ eğitim doğrultusunda kaynaştırma programında bulunan öğrencilere bireyselleştirilmiş eğitim programının hazırlanması gereklidir. Bu sayede öğrencilerin eğitsel gereksinimlerini karşılamak ve ihtiyaç duydukları uyarlamaları gerçekleştirmek mümkün olabilmektedir. Çalışmada, Bireyselleştirilmiş Eğitim Programı (BEP)'in öğrenilmesi, hazırlanması ve uygulamasına ilişkin okul öncesi öğretmenlerinin görüşlerinin belirlenmesi amaçlanmaktadır. $\mathrm{Bu}$ çalışma nitel bir araştırma olup, yüzyüze gerçekleştirilen görüşmelerde yarı yapılandırılmış görüşme formu kullanılmıştır. Araştırmaya 2015-2016 eğitim öğretim yılında görev yapmakta olan, sınıfinda kaynaştırma öğrencisi bulunan 8 okul öncesi öğretmeni katılmıştır. Araştırma sonucunda, öğretmenlerin çoğunluğunun çocuğun gereksinimlerine cevap vermek için BEP hazırlandığı ve BEP hazırlamayı gerekli buldukları sonucuna ulaşılmıştır. Bunun yanında, sınıf içinde fiziksel koşulların olumsuzluğuna yönelik görüşlere yer verilmiştir. Öğretmenlerin çoğu yazılı ve sistematik olarak BEP hazırlamadıklarını, ailelerin ise sürece katılımının düşük olduğunu ifade etmişlerdir. Son olarak, öğretmenler, BEP hazırlanması ve uygulanması ile ilgili kullanıcı dostu yazılı kaynaklara ihtiyaç duyduklarını ifade etmişlerdir.
\end{abstract}

Anahtar sözcükler: Bireyselleştirilmiş eğitim programı, kaynaştırma, okul öncesi, ögretmenler.

\begin{abstract}
Early intervention programs are supporting child development and they also have preventative function. In our country, developing IEP is necessary for addressing educational needs of children with special needs in inclusion programs in early childhood educational settings. This research aims to identify preschool teachers' views on learning, preparing and implementing the Individualized Education Program (IEP). It is a
\end{abstract}

1 Bu çalışma 11-14 Mayıs 2016 tarihinde Muğla Sttkı Koçman Üniversitesi tarafindan düzenlenen XV. Uluslararası Sınıf Öğretmenliği Eğitimi Sempozyumu'nda sözlü bildiri olarak sunulmuștur.

2Yrd. Doç. Dr., Muğla Sttk1 Koçman Üniversitesi, deniztekinersan@gmail.com

3Yrd. Doç. Dr., Muğla Sttk1 Koçman Üniversitesi, sedaata@mu.edu.tr 
qualitative study in which face-to-face, semi-structured interviews were conducted. For the study group, 8 preschool teachers who have students in inclusion programs in 2015-2016 academic year were selected through purposeful sampling According to the findings, the teachers stated that IEP is useful in terms of meeting student's needs in general. Most of the teachers also stated that they did not prepare written and systematic IEPs, and also pointed out low parent involvement during the process. Lastly, the teachers stated that they are in need of easy to use, written resources on developing and implementing IEP.

Keywords: Inclusion, IEP-individualized education program, preschool, teachers.

\section{GíRiș}

Bireyselleştirilmiş eğitim programları (BEP); bireyselleştirme, eğitim programı ve planlamadan oluşan üç temel bileşeni içermektedir. Bu bileşenler çerçevesinde BEP; özel gereksinimi olan bireyin gelişimi ve ona hazırlanan programın gerektirdiği disiplin alanlarında, bireyin eğitsel gereksinimlerini karşılamak üzere belirlenen uygun eğitim ortamlarından (genel eğitim okulu, okul, özel eğitim okulu, özel eğitim sınıfı, mesleki eğitim merkezi vb.) ve destek hizmetlerden (destek eğitim odası, sınıf-içi yardım, dil ve konuşma terapisi, fiziksel rehabilitasyon vb.) en üst düzeyde yararlanmasını öngören yazılı doküman olarak tanımlanmaktadır. Bu doküman aile, öğretmen ve ilgili uzmanların yer aldığı bir ekip ile, işbirliği içinde planlanmakta ve bireyin ailesinin onayı ile uygulanmaktadır (Vuran, 2004). Özel gereksinimi olan bireylerin eğitiminde, gereksinimlerine cevap verebilmek için bireyselleştirilmiş eğitim programlarına ihtiyaç duyulmaktadır. Bu programlar, özel gereksinimi olan öğrencinin bireysel farklılıklarına göre hazırlanmaktadır (Martin, Van Dycke, Christensen Greene, Gardner ve Lovett, 2006). Böylelikle, özel gereksinimi olan öğrencilere, eğitimde firsat eşitliğinin sağlanması konusunda çalışılmaktadır. Bireyselleştirilmiş eğitim programları, öğrencinin bulunduğu kurum tarafından, öğrencinin güncel performansını, uzun ve kısa vadeli hedeflerini, öğrenciye sunulacak özel eğitim hizmetinin türünü, süresini ve öğrencinin buna ne ölçüde katılım sağlayacağını belirleyen programlardır (Fiscus ve Mandell, 2002). Özel gereksinimi olan bireylere özel eğitim sağlanırken, bu programlar mutlaka destek bileşenleri arasında yer almalıdır. Bireyselleştirilmiş eğitim programları, özel gereksinimi olan bireyler ile çalışan uzmanlar tarafından planlanarak hazırlanmalıdır. Bireyselleştirilmiş eğitim programları yöneticiler, öğretmenler, çocuğun gereksinim duyduğu çeşitli uzmanlar, aile ve uygunsa çocuğun kendisinin yer aldığı bir ekip tarafından gerçekleştirilmelidir (Martin, vd., 2006).

Ülkemizde BEP hazırlanmasının yasal dayanakları, 1997 yılında yürürlüğe giren, 573 sayılı Özel Eğitim Hakkında Kanun Hükmünde Kararname ve 2006 yılında yürürlüğe giren Milli Eğitim Bakanlığg'na (MEB) ait, Özel Eğitim Hizmetleri Yönetmeliği’nce ortaya konmuştur. Bu yönetmeliğe göre, okul öncesi dönemde de özel eğitim zorunlu hale gelmiş olup (MEB, 2012), eğitim programlarının bireyselleştirilerek uygulanması esas hale getirilmiştir. $\mathrm{Bu}$ kapsamda, eğitim kurumlarında BEP geliştirme birimi oluşturulması, BEP hazırlanması, uygulanması ve değerlendirilmesi zorunludur. Böylelikle özel 
gereksinimi olan bireylerin ve ailelerinin eğitim gereksinimleri, diğer pek çok ülkede olduğu gibi ülkemizde de, yasal olarak güvence altına alınmıştır (Sucuoğlu ve Kargın, 2006). Ancak uygulamaya bakıldığında, yasa ve yönetmelikler ile ortaya konmuş olan bireyselleştirilmiş eğitim programlarının hazırlanmasında ve uygulanmasında önemli eksiklikler bulunduğu bilinmektedir (Çerezci, 2015; Çuhadar, 2006; Öztürk ve Eratay, 2010). Bu eksikliklerin belirlenmesi ve derinlemesine incelenmesi oldukça önemlidir. Ek olarak, konu ile ilgili öğretmen görüşlerinin belirlenmesinin önemi vurgulanmaktadır (Öztürk ve Eratay, 2010).

Özel gereksinimi olan çocuklarda erken müdahale ve erken dönemde alınan nitelikli özel eğitim hizmetlerinin önemi büyüktür. Erken müdahale programları ile çocuğun tüm gelişim alanları desteklenmekte, bu müdahaleler hem ileriki eğitim hayatlarına olumlu yansımakta hem de koruyucu özellik taşımaktadır. Özel gereksinimi olan çocuklar için erken müdahalenin gerçekleştiği kurumlardan biri de okul öncesi genel eğitim kurumlarıdır. Bu kurumlar kapsamında özel gereksinimi olan çocuklar özel gereksinimi olmayan akranları ile birlikte eğitim alabilmektedirler. $\mathrm{Bu}$ eğitim doğrultusunda kaynaştırma programında bulunan öğrencilere bireyselleştirilmiş eğitim programının hazırlanması gereklidir. $\mathrm{Bu}$ sayede öğrencilerin eğitim gereksinimlerini karşılamak ve ihtiyaç duydukları uyarlamaları gerçekleştirmek mümkün olabilmektedir.

Ülkemizde, okul öncesi öğretmenlerinin gerçekleştirdiği kaynaştırma uygulamalarına bakıldığında, bir takım uygulamalar ve düzenlemeler gerçekleştirilmekle birlikte, bu uygulamaların özel gereksinimi olan çocuğa fayda sağlayabilmesi için daha sistematik hale getirilmesi gerektiği vurgulanmıştır (Özen, Ergenekon, Ülke-Kürkçüoğlu ve Genç, 2013). Bununla birlikte, genel kaynaştırma sorunları içerisinde, öğretmenlerin bireyselleştirilmiş eğitim programı hazırlama ve uygulama konusunda kendilerini yetersiz hissettikleri belirlenmiş ve bu öğretmenlerin bireyselleştirilmiş eğitim programlarını hazırlasalar bile uygulama konusunda yetersiz oldukları ortaya konmuştur (Çerezci, 2015).

Okullarda, BEP'in uygulanmasında öğretmenler rol almakta ve bu öğretmenlerin BEP'in hazırlanması ve uygulanmasına ilişkin bilgi düzeyleri, donanımları ve tutumları öğrencilerin gereksinim duydukları eğitim ve destek hizmetlerinin sunulmasında önem taşımaktadır (Avcıoğlu, 2011). Okul öncesi ögretmenleri ise erken eğitimin sunulduğu okul öncesi kurumlarda, özel gereksinimi olan öğrencilerin gereksinim duyduğu destek ve hizmetleri vermekle yükümlü öğretmenlerdendir. Özel eğitim alanında okul öncesi öğretmenlerinin görüşlerini belirlemeye yönelik çalışmalara bakıldığında, öğretim uygulamalarına yönelik görüşleri (Özen, vd. 2013), çeşitli kaynaştırma uygulamalarını belirlemeye yönelik çalışmalara (Çerezci, 2015) rastlanmıştır. Bu çalışmaların bir kısmında BEP ile ilgili görüşlere kısaca yer verilmiştir. BEP ile ilgili doğrudan ve derinlemesine görüşlerin belirlenmesine yönelik zihin engelliler öğretmenleri (Avcıoğlu, 2011), ilköğretim sınıf öğretmenleri ve yöneticileri (Çuhadar, 2006), sınıf öğretmenleri ve zihin engelliler öğretmenliği mezuniyet alanları olmak üzere eğitim ve uygulama okulu öğretmenleri (Öztürk ve Eratay, 2010), rehber 
öğretmenler (Kuyumcu, 2011) gibi farklı gruplar ile gerçekleştirilmiş çalışmalar bulunmaktadır. Ancak, bireyselleştirilmiş eğitim programı hazırlanması gereken özel gereksinimi olan öğrenciye sahip okul öncesi eğitim kurumlarında gerçekleştirilmiş derinlemesine bir çalışmaya rastlanmamıştır. Bu araştırmada, Bireyselleştirilmiş Eğitim Programı'nın (BEP) öğrenilmesi, hazırlanması ve uygulamasına ilişkin okul öncesi öğretmenlerinin görüşlerinin belirlenmesi amaçlanmaktadır.

\section{YÖNTEM}

$\mathrm{Bu}$ çalışmada nitel araştırma modeli kullanılmış ve okul öncesi öğretmenlerinin Bireyselleştirilmiş Eğitim Programı’nın (BEP) öğrenilmesi, hazırlanması ve uygulanmasına ilişkin görüşleri incelenmiştir. Denzin ve Lincoln’e (1994) göre nitel araştırma, araştırmaya katılan katılımcıların herhangi bir konu üzerine değer yargıları ve inanışlarını kendi yorumlamaları çerçevesinde araştırmacıların önüne sererek derinlemesine anlaşılmasını sağlamaktadır. Dolayısıyla, nitel araştırma bulgularının daha önceden kestirilemezliği ve her bir bulgunun anlamını içinde bulunduğu bağlamda incelenmesine firsat tanıması gibi özgün yönleri ile bu araştırmaya güç katacağı düşünülmektedir.

\section{1. Örneklem/Çalışma Grubu}

$\mathrm{Bu}$ araştırmanın katılımcıları amaçlı örneklem yöntemi ile seçilmiştir.

Tablo 1. Katılımc1 bilgileri

\begin{tabular}{lllll}
\hline Katılımcılar & Yaş & Kıdem & Hizmetiçi eğitim alma & Kaynaştırma deneyimi \\
\hline Ö1 & 33 & 10 & hayır & hayır \\
Ö2 & 35 & 1 & evet & hayır \\
Ö3 & 45 & 25 & evet & evet \\
Ö4 & 30 & 8 & hayır & evet \\
Ö5 & 32 & 10 & evet & hayır \\
Ö6 & 40 & 15 & hayır & hayır \\
Ö7 & 32 & 10 & hayır & evet \\
Ö8 & 37 & 11 & hayır & hayır \\
\hline
\end{tabular}

Çalışmanın katılımcılarını, il merkezine bağlı okul öncesi eğitim kurumlarında görev yapmakta olan ve sınıflarında kaynaştırma öğrencisi bulunan 8 okul öncesi öğretmeni oluşturmaktadır. Bunun için, çalışmanın gerçekleştiği bölgede, sınıfında kaynaştırma programı uygulanan okul öncesi öğretmenlerinin tamamına ulaşılmıştır. Çalışmaya katılım konusunda gönüllülük gösteren öğretmenler ile çalışma gerçekleştirilmiştir. Her biri okul öncesi öğretmenliği mezunu olan öğretmenlerin yaş ortalaması 35,5 olup, 1 ila 25 yıl arasında mesleki kıdeme sahiptirler. Katılımcılara ait bilgilere tablo 1'de yer verilmiştir. 


\subsection{Veri Toplama}

Araştırma verileri, 2016 Bahar döneminde toplanmıştır. Öğretmenlere öncelikle araştırmanın amacı ve içeriğinden bahsedilmiştir. Görüşmelerin araştırmacılar tarafından yapılacağı ve öğretmenlerin gönüllü olarak araştırmaya katılmak istemeleri durumunda görüşmelerin başlayacağı anlatılmıştır. Ayrıca, öğretmenlerin tanınmasına sebep olabilecek kişisel bilgilerinin araştırma raporlarında asla yer almayacağı ve BEP ile ilgili belirttikleri görüşlerin sadece eğitim amaçlı olarak paylaşılacağı bilgisi de kendilerine iletilmiştir. Ardından, öğretmenlerden, araştırmaya katılım için sözlü olarak onay alınmıştır.

Çalışmada veri toplama yöntemi olarak, nitel araştırmalarda sıklıkla kullanılan yarı yapılandırılmış görüşme kullanılmıştır. Çalışmada elde edilen verilere araştırmacılar tarafindan hazırlanan yarı-yapılandırılmış “Bireyselleştirilmiş Eğitim Programı (BEP)'nın öğrenilmesi, hazırlanması ve uygulamasına ilişkin görüşme formu" ile ulaşılmıştır. Uluslararası ve ulusal alanyazına dayanarak araştırmacılar tarafından hazırlanan görüşme soruları için yarı yapılandırılmış görüşmeler konusunda deneyimi olan bir uzmandan uzman görüşü alınmıştır. Uzman görüşü sonrasında görüşme formu son haline getirilmiştir. Bu form, iki kısımdan oluşmaktadır. Birinci kısımda görüşme yapılan öğretmenlerin demografik bilgilerini, ikinci kısımda da "Bireyselleştirilmiş Eğitim Programı" ile ilgili bilgi ve farkındalıklarına yönelik görüşlerini belirmele amaçlı 7 açık uçlu soru yer almaktadır. Görüşmeler, üç araştırmacı tarafından, öğretmenlerin uygun olduğu saatlerde okullarına gidilerek, bireysel olarak yüz yüze yapılmıştır ve yaklaşık olarak 20-30 dakika sürmüştür.

Çalışma verilerinin toplanması sırasında katılımcılardan görüşmelerin kaydı için de izin istenmiştir. Ancak yalnızca üç katılımcı ses kaydı için onay vermiştir. $\mathrm{Bu}$ nedenle diğer katılımcıların verileri, veri toplayan araştırmacılar tarafından o anda yazmak sureti ile kayıt altına alınmıştır (Edwards ve Holland, 2013). Verilerin toplanmasının ardından katılımcılara numaralar verilmiştir. Üçüncü araştırmacı tarafından sorular ve katılımcı görüşleri sütunlarının yer aldığ bir tablo hazırlanmıştır. Her bir araştırmacı, notlarını bu tabloya aktararak görüşme kayıtlarını birleştirmişlerdir. Ardından veri analizi gerçekleşmiştir.

\subsection{Veri Analizi}

Görüşme kayıtları tüm araştırmacılar tarafından incelenerek veri analizi için hazır hale getirilmiştir. Yapılan görüşmelerde öğretmenlerin “Bireyselleştirilmiş Eğitim Programı” üzerine görüşleri betimsel analiz yöntemi ile çözümlenmiştir. Betimsel analiz, elde edilen verilerin daha önceden belirlenen araştırma soruları çerçevesinde belirlenen temalara göre açıklandığı ve yorumlandığı analiz biçimidir (Yıldırım ve Şimşek, 2003). Betimsel analizde öncelikle araştırmanın kavramsal çerçevesinden yola çıkılarak verilerin hangi başlıklar altında analiz edileceği belirlenir. Bu başlıklar altında verilerin işlenme sürecini, araştırma bulgularının tanımlanması takip etmektedir. Araştırma bulguları tanımlanırken gerekli yerlerde katılımcıların görüş ve düşünceleri doğrudan alıntılarla desteklenmektedir. Betimsel analizin son aşamasında ise tanımlanan bulguların yorumlanması ve kavramsal çerçeve ile ilişkilendirilmesi söz konusudur (Yıldırım ve Şimşek, 2003). Bu evrede üç araştırmacı verileri 
incelemiş ve ortak karara varmıştır. Görüşmeler sonucu elde edilen veriler, bir araya toplanmış, detaylı olarak incelenerek okul öncesi öğretmenlerinin BEP üzerine görüşleri altı bölüm altında sunulmuş ve tartışılmıştır.

\section{BULGULAR}

Araştırmaya katılan okul öncesi öğretmenlerinin verdikleri cevaplar doğrultusunda altı ana tema oluşturulmuştur. Bu ortak temalar, BEP hazırlama nedenleri, BEP'in bireysel ve sinıfa yönelik yararları, BEP uygulamalarında yaşanan zorluklar, BEP'in hazırlanma süreci, BEP süreci içerisinde ailenin yeri, öğretmenlerin BEP konusunda destek ihtiyaçları olarak belirlenmiştir. Bulgularda temalar numaralandırılmış, her bir alt tema için görüş bildiren öğretmen sayısına ve örnek alıntılara yer verilmiştir.

\subsection{BEP Hazırlama Nedenlerine İlişkin Bulgular}

Öğretmenler BEP hazırlama nedeni olarak en çok çocukların gelişimlerini destekleyip ihtiyaçlarına cevap verebilmek (6/8) için BEP hazırlanması gerektiğini vurgulamışlardır. Ayrıca, bir öğretmen de BEP in kendini yönlendiren bir rehber olmasından dolayı BEP hazırlamanın önemini belirtmiştir. Diğer bir öğretmen ise bu konuda fikir beyan etmemiştir. Bu temaya ilişkin öğretmenlerin görüşlerinden bazıları şunlardır;

"Bireysel ihtiyaçlarına en iyi cevap verecek yöntem olduğu için olumlu baklyorum”(Ö7)

“Öğretmenin ne yapıp ne yapmayacă̆ını bilmesine yardımcı olacă̆ını düşünüyorum. Böylelikle ögrretmen ne yapıp ne yapmayacă̆ konusunda sürekli kendisini kontrol edip zenginleştirebilir..."(Ö3)

\subsection{BEP'in Bireysel ve Sınıfa Yönelik Yararlarına İlișkin Bulgular}

Öğretmenler genel olarak BEP'in yararlı olduğundan bahsetmişlerdir (6/8). İki öğretmen ise BEP'i yararlı bulmadıklarını ifade etmişlerdir. Öğretmenler BEP'in sınıf içi uygulamalara katkı sağlayarak daha iyi bir sınıf yönetimi sergilenmesinde rol oynadığından (3/6) ve çocukların gelişimlerini desteklemeye yönelik yararları (3/6) olduğundan bahsetmişlerdir. $\mathrm{Bu}$ temaya ilişkin öğretmenlerin görüşlerinden bazıları şunlardır;

"Çocuğun gelişimini desteklemek ve seviyesine inebilmek için. Sinıf içinde çocuk böylelikle sinıfla kaynaşabilir ve bu çocuğun sınıfta böylelikle daha istekli bir şekilde katılma isteği sergilediğini gördüm..."(Ö1)

"Sınıfta daha iyi bir sınıf yönetimi sergilemek için yararlı olabilir. Bunun yanında çocuğun hem özel eğitim kurumundaki eğitimi hem benim verdiğim ĕgitimle gelişimi desteklenerek sınıf içinde kendini daha iyi ifade edebilir...”(Ö2)

"Bu çocuklar tabi ki okula gelmesin demiyorum ancak Bep'in katkı sağladığını düşünmüyorum ..." (Ö6)

\section{BEP Uygulamada Yaşanan Zorluklara İlişkin Bulgular}


Öğretmenler uygulamada yaşanan zorluklarla ilgili olarak sınıfın fiziksel koşullarının yetersizliği ve sınıf mevcudunun kalabalık olmasını (4/8) dile getirmişlerdir. Ayrıca, yine öğretmenlerin sınıflarında yardımcı öğretmenin bulunmamasının (4/8) da BEP'in uygulamalarına olumsuz olarak yansıdığını ortaya koymuşlardır. Bu temaya ilişkin öğretmenlerin görüşlerinden bazıları şunlardır;

“Kalabalık sinıf olması BEP'in uygulanmasinı engelliyor. Planı usulüne uygun hazırlasam bile uygulama konusunda sinıfta herhangi yardımcı bir yetişkinin olmaması sıkıntı yaratıyor... “(Ö3)

"Öğrenci sayımız çok fazla, yardımcı elemanımız yok. Birde ögrencimin saldırgan davranışlarl var, bazen zorlanıyorum”(Ö7)

\section{BEP Hazırlama Sürecine İlişkin Bulgular}

BEP hazırlama sürecine ilişkin genel olarak öğretmenler, yazılı ve sistematik bir BEP'in olmadığını (7/8) ve BEP ekibinin toplanmadığını (6/8) ifade etmişlerdir. Ayrıca, iki öğretmen de rehber öğretmenin BEP hazırlama sürecinde hiç katkı sağlamadığını belirtmişlerdir. $\mathrm{Bu}$ temaya ilişkin öğretmenlerin görüşlerinden bazıları şunlardır;

"Kendimiz bir şekilde araştırıp plan hazırlayıp plan doğrultusunda hareket etmeye çalışlyoruz. Çocukların tabi farklılıkları var onları göz önünde bulunduruyoruz. Her çocuğa ayrl, hem ortak bir nokta bulmaya çalışıyorum hem de çocukların kişisel özellikleri, duyuşsal özellikleri, bilişsel özelliklerini bir araya getirmeyi düşünüp onlarla ortak bir nokta bulup hazırlamaya çalışıyorum ... Ancak biz hazırlamıyoruz. Yani okul öncesinde BEP hazırlanmiyor..."(Ö5)

"Herhangi bir şekilde BEP yapmiyoruz. Bu konuda rehber ögretmenin hem bilgisi hem de ilgisi yok. Hiç yardımcr olmad1..."(Ö3)

\section{BEP Süreci İçerisinde Ailenin Yerine İlişkin Bulgular}

Öğretmenlerden hiçbiri ailenin BEP sürecine dahil olduğuna yönelik bir söylemde bulunmamışlardır. Bunun yanında, öğretmenlerin genel olarak aileyle iletişim ve işbirliği içinde olmadıklarını (5/8) belirtmişlerdir. Üç öğretmen de aile ile iletişim ve işbirliğini sağladıklarını ifade etmişlerdir. $\mathrm{Bu}$ temaya ilişkin öğretmenlerin görüşlerinden bazıları şunlardır;

"Aileyle iletişim halindeyim. Yapılan etkinliklerin evde desteklenmesi için ev ödevleri gönderiyorum.”(Ö1)

"Özellikle bu süreçte aile desteğinin olması gerekiyor. Ancak karşınıza oturtup konuşabileceğiniz bir aile yok zaten. Bir kere ailenin önce bir eğitim almasl gerekiyor."."

\section{Bulgular}

6. Öğretmenlerin BEP Konusunda Destek İhtiyaçlarına İlişkin

Öğretmenler genel olarak BEP konusunda yazılı kaynağa ihtiyaç duyduklarını (5/8) belirtmişlerdir. Ayrıca, öğretmenler bilgilendirici eğitimlere de 
ihtiyaç duyduklarını (3/8) ifade etmişlerdir. Bu temaya ilişkin öğretmenlerin görüşlerinden bazıları şunlardır;

"Hem bilgi seviyemi arttracak hem de farkl uygulama örneklerini sunan piyasada kaynak bulmakta zorlanıyorum "(Ö2)

“..Seminerler düzenlenebilir. Mesela bizim haziran ve eylül dönemlerindeki seminer dönemlerimizde boş boş okulda oturacă̆ımıza bu konularla ilgili bize özel olarak seminerler düzenlense ne bileyim sempozyumlara katılsak çok mükemmel olur. Birebir iletişime geçebilmeliyim bence o hocalarla yani örnek olarak alo deyip hocam böyle bir sorunumuz var ne yapabiliriz demeliyim..."(Ö5)

\section{TARTIŞMA ve SONUÇ}

$\mathrm{Bu}$ araştırmada sınıfında kaynaştırma öğrencisi bulunan okul öncesi öğretmenlerinin Bireyselleştirilmiş Eğitim Programı (BEP) hazırlanmasına ilişkin görüşleri incelenmiştir. Araştırmadan elde edilen bulgulara dayanarak; genel olarak öğretmenler, BEP'i öğrencilerin ihtiyaçlarına cevap vermesi bakımından yararlı bulduklarını ifade etmişlerdir. Öğretmenlerin bu ifadelerinin, BEP uygulamalarının çocukların gelişimlerini desteklediğini belirten araştırma sonuçlarıyla (Örn, Tazebaş, 2000; Diamond ve Carpenter, 2000) paralellik gösterdiği söylenebilir. Ayrıca, bir öğretmen de BEP'in öğretmenler için bir rehber görevi üsteleneceğini ifade etmiştir. Mevcut bulgunun Öztürk ve Eratay’ın (2010) BEP'in zihinsel engelli çocuğa, velilere ve öğretmenlere yararı olduğunu ortaya koydukları araştırması tarafından desteklendiği söylenebilir.

Öğretmenlerin BEP'in sınıf içerisinde özellikle sınıf yönetimi konusunda da yarar sağlayacağıyla ilgili görüş belirttikleri görülmüştür. Öğretmenlerin bu görüşleri sınıfında kaynaştırma öğrencisi bulunan çocukların sınıf içi davranışları konusunda öğretmenlerin yetersiz kaldıklarını ifade eden Akalın ve diğerlerinin (2014) yapmış oldukları araştırmayla benzerlik taşıdığı düşünülebilir. Bu noktada, öğretmenlerin BEP ile ilgili görüşleri çelişebilmektedir. Bu çelişkinin nedeninin öğretmenlerin BEP ile ilgili bilgi eksiklikleri olduğu söylenebilir.

Öğretmenlerin bir kısmı, BEP uygulamaları konusunda yaşanan zorlukları, sınıfın fiziksel şartlarının istenilen düzeyde olmamasına ve sınıf mevcudunun fazla olmasına bağlamışlardır. Öğretmenlerin bu gerekçelerinin, ilgili alan yazında fiziksel koşulların uygulamada yaşanabilecek bir takım güçlüklere sebep olabileceğini belirten araştırma sonuçlarıyla (Arslantas, Kurnaz, Koçak, Çalıkçı ve Durdal, 2008; Öztürk ve Eratay, 2010; Odom, 2000; Altun ve Gülben, 2009; Gök ve Erbaş, 2011) paralellik gösterdiği düşünülmektedir. 8 öğretmenden diğer 4'ü ise sınıfta yardımcı personelin bulunmamasını BEP uygulamaları karşısında bir engel olarak tanımlamışlardır. Bu bulgunun Ada, Küçükali, Akan ve Dal (2014) tarafından gerçekleştirilen, okul öncesi öğretmenlerinin yardımcı personelin azlığına ilişkin sorunlar yaşadıklarını ortaya koyan araştırma sonucuyla benzer nitelik taşıdı̆̆

Öğretmenler BEP sürecinin uygulanmadığını ve hazırlama konusunda bir takım çabalar göstermelerine rağmen bilgi eksikliklerini vurgulamışlardır. Bu 
bulgu, öğretmenlerin BEP hazırlama konusunda bilgi düzeylerinin yetersizliğini ortaya koyan araştırma sonuçlarıyla desteklenebilir (Öztürk ve Eratay, 2010; Altun ve Gülben, 2009; Gök ve Erbaş, 2011). Ayrıca, öğretmenlerin bir bölümü rehber öğretmenlerle bu süreçte iyi bir iletişim kuramadıklarını ve onlardan gerekli desteği alamadıklarını da belirtmişlerdir. Bu durum, ilgili alan yazında rehber öğretmenlerin kaynaştırma uygulamalarında önemli rol ve sorumlulukları (örn, Özengi, 2009) olduğu belirtilmiş olmasına rağmen araştırmaya katılan okul öncesi öğretmenlerine göre rehber öğretmenlerin BEP sürecinde aktif bir rol oynamadıklarını göstermektedir. Bununla beraber, rehber öğretmenlerin bu tutumlarının, kaynaştırma sürecine ilişkin rehber öğretmenlerin bilgi ve becerilerinin yeterli olmadığını ortaya koyan araştırma sonuçlarıyla (Akalın, 2014; Aliyev vd., 2012) paralellik gösterdiği düşünülmektedir. Ancak bu noktada, araştırma katılımcılarının, yapılan görüşmeler sonucunda, BEP ekibinin rolleri ve bir ekip üyesi olarak okul öncesi öğretmenlerinin kendilerine düşen roller konusunda bilgilerinin yetersiz olduğu sonucuna da ulaşılmıştır. Dolayısıyla, okul öncesi öğretmenlerinin, rehber öğretmenlere ilişkin beklentilerinin yükselmesine neden olduğu düşünülmektedir.

Genel olarak öğretmenler BEP sürecinde katılımları önemsenen aileyle işbirliği ve iletişim sağlayamadıklarını ifade etmişlerdir. BEP sürecinin temelini, aile ile okul arasında etkili bir iletişim ve işbirliğinin sağlanması, ailelerin çocukların eğitim hakları konusunda karar alma sürecinde yer alması ve çocukların eğitimindeki görev ve sorumluluklarını öğrenmeleri oluşturmaktadır (Santos, 2012). Ancak mevcut bulgu, öğretmenlerin aile katılımının sağlanmasında bir takım zorluklar yaşandığını gösteren araştırma sonuçlarıyla (Öztürk ve Eratay, 2010; Avcığlu, 2012) açıklanabilir. Buna ek olarak, BEP'in sağlıklı bir şekilde yürütülmesinde sürecin hazırlık aşamasında diğer velilerin bilgilendirilmesine ve bu süreçle ilgili herhangi bir görüşme ya da toplantı planlamadıkları da görülmüştür. Çocukların tutumlarını olumlu yönde etkilemek için en önemli kaynaklardan biri de hem özel gereksinimli hem de normal gelişim gösteren çocukların ailelerinin kaynaştırma eğitimi konusunda bilgilendirmektir (Başal, 2003). Bu durum da bu araştırmaya katılan öğretmenlerin okul öncesi eğitimin vazgeçilmez bir unsuru olan aile iletişim ve işbirliği konusunda yeterli bilgi ve beceriye sahip olmadığı düşünülmektedir. Özellikle bu araştırmaya katılan öğretmenler ailenin süreçte isteksizliğini vurgularken, aile işbirliğinin gerçekleştirilmesindeki rollerine ilişkin herhangi bir açıklamada bulunmamışlardır.

Araştırma sonuçlarına göre BEP sürecinde öğretmenlerin kaynaklara ulaşma (kitap ve materyal gibi), seminer ve uzman desteğine ihtiyaç duydukları görülmüştür. Bu durumun BEP hazırlama sürecinde materyalin son derece önemli olduğunu belirten bir araştırma bulgusu (Menlove, Hudson ve Suter, 2001) tarafından desteklendiği söylenebilir. Ayrıca, ilgili alan yazında öğretmenlerin kaynak ve uzman kişilerin desteğini talep ettikleri araştırma sonuçlarıyla (Gök ve Erbaş, 2011; Özen, Ergenekon, Kürkçüoğlu ve Genç, 2013; Sucuoğlu, Ünsal ve Özokçu, 2004) benzer niteliktedir. 
Kaynaştırma öğrencilerinin özel gereksinimlerini karşılamaya yardımcı olmak için okul öncesi öğretmenlerine önemli görevler düşmektedir. Ancak, öğretmenlerin BEP sürecine ilişkin bilgi eksikliklerinin ve bir takım yanlış bilgilerinin olduğu görülmüştür. BEP sürecinin verimli bir şekilde yürütülmesinde kendi sorumluluklarına vurgu yapmaktan kaçınan okul öncesi öğretmenleri, en çok rehber öğretmenlerin sorumluluklarını yerine getirmemelerinden bahsetmişlerdir. $\mathrm{Bu}$ durum kendi rol ve sorumluluklarını yerine getirme konusunda kaçınmacı bir tavra sahip olmalarıyla açıklanabilir. BEP sürecinde aktif rol oynaması gereken birçok uzman olsada öncelikle o sınıftan sorumlu olan okul öncesi öğretmeninin kendi rol ve sorumluluğunu kabul etmesi gerekmektedir. Buna ek olarak, bu araştırma sonuçlarına dayanarak, BEP ekibinin önemli bir basamağı ve parçası olan okul öncesi öğretmenlerinin yeterli donanım ve desteğe sahip olmamalarının da BEP sürecini olumsuz olarak etkileyen faktörler arasında olduğu düşünülmektedir. BEP sürecine başlamadan önce atılması gereken bir takım önemli adımlar bulunmaktadır. Öncelikle bir okul öncesi eğitim ortamında gerçekleştirilecek tüm eğitim faaliyetlerinin gerçekleştirilebilmesinde çocuğu tanımak ve değerlendirmek kritik bir önem taşır. Ayrıca sınıfında kaynaştırma öğrencisi olan öğretmenlerin çocukların ihtiyaçlarının belirlenmesine yönelik herhangi bir çalışma yapmadıkları görülmüştür.

Ülkemizde kaynaştırmayla ilgili yasa ve düzenlemelere rağmen etkili ve nitelikli bir kaynaştırma eğitimi için özellikle öğretmenlere ve öğrencilere yeterli destek hizmeti verilmesi gerekmektedir. Özellikle BEP süreci ve tüm kaynaştırma uygulamalarının sağlıklı bir şekilde bir planlanıp yürütülebilmesi için eğitimcilere, öğrencilere ve ailelere yeterli destek hizmeti verilmesi gerekmektedir. BEP uygulamalarının sınıfın ve okulun öğrenci özelliklerine göre düzenlenmesi, öğrenci davranışlarına nasıl müdahale edilmesi gerektiği, etkili bir davranış yönetiminin nasıl yaratılabileceği gibi konularda bilgilendirmeler ve gerekli materyallerin öğretmenlere sunulmasının BEP uygulamalarının yaratacağı olumlu etkiyi arttıracağı düşünülmektedir.

$\mathrm{Bu}$ araştırmanın bir takım sınırlıkları bulunmaktadır. Elde edilen bulgular sadece sınıfında kaynaştırma öğrencisi olan ve uygun örnekleme yoluyla seçilen sekiz okul öncesi öğretmeniyle sınırlıdır. Bu araştırmanın sınırlılıkları ve sonuçları bağlamında şu önerilerde bulunulabilir:

- BEP özel gereksinime sahip tüm öğrencilerin uygun öğrenme ortamlarını sağlayarak gelişimlerinin desteklenmesini merkeze alan önemli bir programdır. $\mathrm{Bu}$ programın ilk uygulanacağı basamak olan okul öncesi eğitim ortamlarında farklı araştırma yöntemleri ışı̆̆ında çalışmalar yürütülebilir.

- Sınıflarında kaynaştırma öğrencisi bulunan okul öncesi öğretmenlerine kullanıcı dostu ve erişimi kolay materyaller sunulabilir.

- Okul öncesi eğitim amaçlarının gerçekleştirilmesinde etkili sınıf yönetimi ve olumlu sınıf atmosferi sağlayabilmek kritik bir önem taşımaktadır. Etkili bir sınıf yönetimi ve olumlu sınıf atmosferi ise özellikle sınıfında kaynaştırma öğrencisi bulunan eğitim ortamında daha çok önem kazanmaktadır. $\mathrm{Bu}$ nedenle öğretmenlere, sınıflarında meydana gelebilecek problem davranışları önlemede, önleyici sınıf yönetimi becerilerine ilişkin bilgilendirme yapılabilir. 
- MEB'in hizmet içi eğitimleri kapsamında var olan BEP modülü yaygınlaştırılabilir. $\mathrm{Bu}$ modüllerin oluşturulmasında yapılan araştırma sonuçları daha çok göz önünde bulundurulabilir.

- Öğretmenlere sunulan rehberlik içerikli denetimlerin arttırılarak konu ile ilgili geri bildirimler sağlanabilir.

- Eğitim fakültesinden mezun bir öğretmenin belli yeterliliklere sahip olması gerektiği düşünülmektedir. Bu yeterliliklerin en önemlilerinden birisi de BEP sürecinin etkin bir şekilde yürütülmesidir. Başta okul öncesi öğretmenliği programı olmak üzere öğretmen yetiştirme programları içerisinde bulunan özel eğitim dersinin uygulamaya dönük olarak genişletilmesi ve yetkin öğretim elemanları tarafından yürütülmesi önerilebilir. 


\section{KAYNAKLAR}

Ada, Ş., Küçükali, R., Akan, D. ve Dal, M. (2014). Okul öncesi eğitim kurumlarında yönetim sorunları. Middle Eastern \& African Journal of Educational Research, (12), 32-49.

Akalın, S. (2014). Okul öncesi eğitim kurumlarında çalışan rehber öğretmenlerin kaynaştırma uygulamalarına ilişkin gereksinimleri. International Journal of Early Childhood Special Education (INT-JECSE), 6(1), 115 - 142.

Akalın, S., Demir, Ş., Sucuoğlu, B., Bakkaloğlu, H., \& İşcen, F. (2014). The needs of inclusive preschool teachers about inclusive practices. Eurasian Journal of Educational Research, 54(1), 39-60.

Aliyev, R., Erguner-Tekinalp, B., Ulker, R., \& Shine-Edizer, F. (2012). The perceptions of school counselors and principals towards new psychological counseling and guidance services in early childhood education in Turkey. Educational Sciences: Theory \& Practice, 12, 3083-3098.

Altun, T. ve Gülben, A. (2009). Okul öncesinde özel gereksinim duyan çocukların eğitimindeki uygulamalar ve karşılaşılan sorunların öğretmen görüşleri açısından değerlendirilmesi [Çevrimiçi sürüm]. Ahmet Keleşoğlu Eğitim Fakültesi Dergisi, 28, 253-272.

Arivett, D.L., Rust, J.O., Brissie, J.S., \& Dansby, V.S. (2007). Special education teachers' perceptions of school psychologists in the context of individualized education program meetings. Education, 127(3). 378-388.

Arslantas, S., Kurnaz, A., Koçak, F., Çalıkçı, N.M., ve Durdal, . (2010). 18. Ulusal Özel Eğitim Kongresi'nden Yansımalar. 13-15 Kasım 2009-Konya. Bugünden Geleceğe Özel Eğitim. H. Sarı (Ed.). Özel Eğitime İhtiyacı Olan Bireylerle Çalışan Öğretmenlerinin Bireysel Eğitim Planlarının Hazırlanması ve Uygulanması ile İlgili Görüşlerinin Değerlendirilmesi. (167-178). Konya: Master Fotokopisi.

Avcıoğlu, H. (2012). Rehberlik ve Araştırma Merkezi (RAM) müdürlerinin tanılama, yerleştirme-izleme, bireyselleştirilmiş eğitim programı (BEP) geliştirme ve kaynaştırma uygulamasında karşılaşılan sorunlara ilişkin algıları. Kuram ve Uygulamada Ĕgitim Bilimleri, 12 (3), 2009-2031.

Avcıoğlu, H. (2011). Zihin engelliler sınıf öğretmenlerinin bireyselleştirilmiş eğitim programı (BEP) hazırlamaya ilişkin görüşleri. Ankara Üniversitesi Ĕ̈itim Bilimleri Fakültesi Özel Ĕ̈itim Dergisi, 12(01), 039-053.

Başal, M. (2003). Okul Öncesi Dönemde Özel Ĕgitim. Anadolu Üniversitesi Açıköğretim Fakültesi Yayını, 756, 29-42.

Çerezci, Ö. (2015). Okul öncesi ĕgitim kurumlarında yapılan kaynaştırma ĕgitimi uygulamalarının kaynaştırma kriterleri açısından değerlendirilmesi. Yayınlanmamış yüksek lisans tezi. Ankara: Gazi Üniversitesi, Eğitim Bilimleri Enstitüsü.

Çuhadar, Y. (2006). İlköğretim okulu 1-5. sınıflarda kaynaştırma ĕgitimine tabi olan öğrenciler için bireyselleştirilmiş eğitim programlarının hazırlanması, uygulanması, izlenmesi ve değerlendirilmesi ile ilgili olarak 
sınıf öğretmenleri ve yöneticilerin görüşlerinin belirlenmesi. Yayımlanmamış yüksek lisans tezi, Zonguldak: Zonguldak Karaelmas Üniversitesi, Sosyal Bilimler Enstitüsü.

Denzin, N. K. ve Lincoln, Y. S. (1994). Introduction: Entering the field of qualitative research. In N. K. Denzin ve Y. S. Lincoln. (eds.), Handbook of Qualitative Research (s. 1-17). Thousand Oaks, CA: Sage.

Diamond, K. E. ve Carpenter, E.S. (2000). Participation in inclusive preschool programs and sensitivity to the needs of others. Journal of Early Intervention, 23 (2), 81-91.

Edwards, R. ve Holland, J. (2013). What's qualitative interviewing? Bloomsbury Academic Publishing, PLC: London.

Fiscus, D. E. ve Mandell, J. C. (2002). Bireyselleştirilmiş Eğitim Programlarının Geliştirilmesi. (G. Akçamete, H.G. Şenel ve E. Tekin, Çev.). Ankara: Anı.

Gök, G. ve Erbaş, D. (2011). Okul öncesi öğretmenlerinin kaynaştırma eğitimine ilişkin görüşleri ve önerileri. International Journal of Early Childhood Special Education, 3 (1), 66-87.

Kargın, T. (2007). Eğitsel değerlendirme ve bireyselleştirilmiş eğitim programı hazırlama süreci. Ankara Üniversitesi Ĕ̈itim Bilimleri Fakültesi Özel Ĕ̈itim Dergisi, 8(01), 01-16.

Kuyumcu, Z. (2011). Bireyselleştirilmiş ĕgitim planı (BEP) geliştirilmesi ve uygulanması sürecinde ögretmenlerin yaşadıkları sorunlar ve bu sorunlara yönelik çözüm önerileri. Yayınlanmamış Yüksek lisans tezi. Ankara: Ankara Üniversitesi, Eğitim Bilimleri Enstitüsü.

Martin, J. E., Van Dycke, J. L., Christensen, W. R., Greene, B. A., Gardner, J. E., \& Lovett, D. L. (2006). Increasing student participation in IEP meetings: Establishing the self-directed IEP as an evidenced-based practice. Exceptional Children, 72(3), 299-316.

Menlove, R., Hudson, P., \& Suter, D. (2001). A field of IEP dreams increasing general education teacher participation in the IEP Development Process. Teaching Exceptional Children, 33(5), 28-33.

Odom, S. L. (2000). Preschool inclusion: What we know and where we go from here. Topics in Early Childhood Special Education, 20, 20-27.

Özen,A., Ergenekon, Y., Ülke-Kürkçüoğlu, B. ve Genç, D. (2013). Kaynaştırma Öğrencisi Olan Okulöncesi Öğretmenlerinin Sınıflarında Yaptıkları Öğretim Uygulamalarının Belirlenmesi (Teaching Practices Used by Preschool Teachers Who Have Mainstreamed Students in Their Classrooms). Anadolu Üniversitesi Sosyal Bilimler Dergisi, 13 (2), 153166.

Özengi, S., (2009). Eskişehir ilinde kaynaştırma uygulamalarının yürütüldüğü ilkögretim okullarındaki rehber öğretmenlerin kaynaştırmaya ilişkin görüşleri. Yayınlanmamış yüksek lisans tezi, Eskişehir: Anadolu Üniversitesi, Eğitim Bilimleri Enstitüsü. 
Öztürk, C. Ç. ve Eratay, E. (2010). Eğitim uygulama okuluna devam eden zihin engelli öğrencilerin öğretmenlerinin bireyselleştirilmiş eğitim programı hakkındaki görüşlerinin belirlenmesi. Abant İzzet Baysal Üniversitesi Dergisi, 10 (2), 145-159.

Santos, M., Duman, B., Erişkin, A. Y., Başar, M. C., Kıraç, S., ve Toraman, Ç. (2012). Education Program (IEP). Cerebral Palsy Trainee Booklet, 91.

Sucuoğlu, B., Ünsal, P. Ve Özokçu, O. (2004). Kaynaştırma sınıfı öğretmenlerinin önleyici sınıf yönetimi becerilerinin incelenmesi. Ankara Üniversitesi Ĕgitim Bilimleri Fakültesi Özel Eğitim Dergisi, 5 (2), 51- 64.

Sucuoğlu, B. ve Kargın, T. (2006). Ilköğretimde Kaynaştırma Uygulamaları: Yaklaşımlar, Stratejiler, Yöntemler. İstanbul: Morpa Yayınları.

Tazebaş, B. (2000). Görme engelli ögrencilere, belirlenen rotalar boyunca bağımsız hareketlerin kazandırllmasında fiziksel yardım ve sözel ipucuyla sunulan bireyselleştirilmiş rota ögretim materyalinin etkililiği. Tez Çalışması. Ankara: Gazi Üniversitesi Eğitim Bilimleri Enstitüsü.

Yıldırım Doğru, S. S. (2011). Bireyselleştirilmiş eğitim programları. S. Sunay Yıldırım Doğru (Ed.), Erken Çocukluk Döneminde Özel Eğitim içinde (s. 150-167). Ankara: Maya Akademi.

Yıldırım, H. ve Şimşek, A. (2008). Sosyal Bilimlerde Nitel Araştırma Yöntemleri. Ankara Seçkin Yayıncılık.

Vuran, S. (2004). Bireyselleştirilmiş Eğitim Programlarının Geliştirilmesi. O. Gürsel (Ed.) Bireyselleştirilmiş Eğitim Programlarl. (1-12). Eskişehir: Anadolu Üniversitesi Yayınları. 


\section{Introduction}

\section{EXTENDED ABSTRACT}

The Individualized Education Program (IEP) is implemented by teachers at schools, and teachers' knowledge, beliefs and attitudes regarding the development and implementation of IEP, are of importance in offering students the educational and support services they are in need of (Avcioğlu, 2011). Preschool teachers are responsible for providing students in special need with the support and services they need at preschool institutions where early education is given. As for the studies aiming to identify preschool teachers' opinions in the field of special education, it is observed that some of them are on instructional practices (Özen et al., 2013) and some others aim to determine several inclusion practices (Çerezci, 2015). Although there are studies on IEP performed with different samples, such as teachers of the students with intellectual disability (Avcioğlu, 2011), elementary school classroom teachers and administrators (Çuhadar, 2006), special education school teachers under the graduation fields of classroom teaching and special education teaching (Öztürk \& Eratay, 2010), school counselors (Kuyumcu, 2011), but there is not any study performed in depth with preschool education teachers at early childhood education settings where students are in special need and an individualized education program needs to be created. This study aims to identify preschool teachers' views on learning, developing and implementing the Individualized Education Program-IEP.

\section{Methods}

This qualitative study aimed to examine a group of preschool teachers' views on learning, developing and implementing the Individualized Education Program and to see whether they are knowledgable and aware of the issues related with IEP. Eight preschool teachers who have inclusion students in their classrooms selected through purposeful sampling, were interviewed face to face and the data were examined through descriptive content analysis.

\section{Results and Discussions}

Results of the study were presented under six major themes including reasons for developing an IEP, individual and in-class benefits of IEP, challenges in the implementation of IEP, preparation phase of IEP, family's position during the IEP process, and teachers' need for support in IEP.

According to the findings, the teachers find IEP useful in terms of meeting student needs in general. Teachers also stated that IEP would bring benefit in their classroom management. Some of the teachers defined the challenges in the implementing process of IEP as inadequate physical conditions of the classroom and redundancy of the class size. The teachers mentioned that although they make efforts for IEP preparation, they can hardly implement IEP in their classrooms due to their lack of knowledge. This finding can be supported by the research results showing teachers' lack of knowledge on preparing and implementing an IEP (Öztürk \& Eratay, 2010; Altun \& Gülben, 2009; Gök \& Erbaş, 2011).

In general, the teachers asserted that they cannot secure cooperation and communication with parents of which participation in the IEP process is considered important. It can be concluded from this finding that the teachers do not have sufficient knowledge and skills on parent communication and 
cooperation which is an indispensible element of preschool education. While the teachers emphasized the unwillingness of parent during the process, they did not make any explanation about their roles in securing parent cooperation.

According to the research results, the teachers are in need for access to sources (books and materials, etc.), seminars and expert support. It can be said that this result is in parallel with another research result indicating how important materials are in the preparation stage of an IEP (Menlove, Hudson \& Suter, 2001).

Preschool teachers play significant role in inclusion programme which meets students' special needs. Yet, it is seen that the teachers have lack of knowledge and certain misinformation about IEP process. Avoiding the emphasis on their own responsibilities in the efficient implementation of the IEP process, the participants mentioned about how school counselors do not fully support them. This can be explained by the fact that the teachers assume an avoidant attitude towards delivering their own roles and responsibilities. Although there are several partners who should play an active role in the IEP process, a preschool teacher, who is in charge of preschool classroom, needs to accept his/her own role and responsibility. In addition, preschool teachers, who play critical role in IEP team, do not have the sufficient equipment and support. In this essence, these factors influence the IEP process in a negative way. There are certain important steps to be taken into consideration before commencing the IEP process. Primarily, getting to know and evaluating a child is of critical importance in carrying out all the educational activities in a preschool education setting. Moreover, it is observed that the teachers with inclusion students in their classes provide no studies aiming to identify their needs.

Despite the laws and regulations on inclusion education in Turkey, it is necessary to provide teachers and students with adequate amount of support for an effective and quality inclusion education. Educators, students and families should be provided with the necessary support so that especially the IEP process and all inclusion practices can be planned and implemented thoroughly. Supporting teachers with necessary information and equipment on organization of IEP practices in accordance with the classroom properties and student characteristics, intervention techniques to student behaviors and implementation of an effective method of behavior will increase the positive impact to be imposed by IEP practices. 